$\left.\begin{array}{c}\text { Sournals } \\ \text { INTERNATIONAL JOURNAL OF } \\ \text { ORGANIZATIONAL LEADERSHIP }\end{array}\right) \begin{gathered}\text { INDUSTRIAL } \\ \text { MANAGEMENT } \\ \text { INSTITUTE }\end{gathered}$

\title{
Materialism and its Associated Concepts
}

\author{
Bahar Türk ${ }^{* 1}$, Aysel Erciş² \\ ${ }^{1} \mathrm{PhD}$, Department of Marketing, Campus Box 25240, Atatürk University, Erzurum, Turkey \\ ${ }^{2}$ Professor, Department of Marketing, Campus Box 25240, Atatürk University, Erzurum, Turkey
}

\begin{abstract}
Keywords:

Consumer Behavior,

Materialism, Consumption

Style, Structural Equations

Model

Received

25 November 2016

Received in revised form

12 November 2017

Accepted

24 November 2017

Correspondence:

bahar.turk@atauni.edu.tr

Consumption tendency have increased in society and individuals have preferred their tendency rather than needs in their purchasing process. This situation has increased the tendency toward materialism. Therefore, it is important to determine the relationship between materialism and other variables which affect the purchase decision. Some of these factors are perceived social status, status consumption, conspicuous consumption, impulse buying, brand loyalty, consumer independence, and materialism of the consumers. In this context the aim of this paper was to examine the relationships between materialism, perceived social status, status consumption, impulse buying, conspicuous consumption, brand loyalty, and consumer independence. The survey was applied to 412 people in Erzurum/Turkey. To investigate the relationship between these variables, the structural equations model was used. The findings indicated that there was a positive relationship among materialism, status consumption, perceived social status, conspicuous consumption, impulse buying, and brand loyalty. Another significant finding pointed out that materialism was not associated with consumer independence.
\end{abstract}

(C)AIMI Journals

Consumers play a significant role in the marketplace and have unique characteristics that respond differently to every product or services. There are many factors that influence the consumers' buying behavior. Some of these factors are perceived social status, status consumption, conspicuous consumption, impulse buying, brand loyalty, consumer independence, and materialism of the consumers.

Materialism is often connected with faith in literature at the 1980s. During that period, it captured the attention of marketers. On the other hand, the consumption literature is fairly vast and varied; in this literature, materialism is defined as "accepting worldly possessions above all 
other things and perceive it as a source of happiness" (Belk, 1987; Belk \& Pollay, 1985). The relationship between people and material goods is undoubtedly fundamental to the concept of materialism (Ger \& Belk, 1996) and materialism now seems to have spread out more of the world's people like a technological invention or new trends. Several researchers have found perceive social status to be associated with materialism (Fah, Foon, \& Osman, 2011). The consumption pattern of materialistic consumers with a high disposition is specified based on the perceived social status. Especially in developed nations, people give importance to their status for showing their places in the society or for holding a position. Moreover, it is recognized that people aspire to be honored by having products which are signs of high status. Hence, perceived social status brings about "status consumption". Moreover, conspicuous consumption is connected to both a perceived higher status in society and materialism. Impulse buying is a wide aspect of consumers' behaviors and a focus for considerable marketing activity. The impulse buying is defined as 'stimulation of the moment and purchase that comes with it' (Rookh, 1987). Also, works show that consumers feel jealous or envious when others acquire a greater number of possessions. So we believe that there exists a positive relationship between materialism and impulse buying (Podoshen \& Andrzejewski, 2012). Brand loyalty takes place among the factors known to affect purchase behavior. Consumers usually tend to purchase brands which specifically designate or mark a desired social status. Similarly, materialistic consumers see the brand product as a source of happiness. In this regard, consumers will continue to purchase the brand product that they believe make them happy and will avoid perceived unhappiness.

Also, independent consumers are unconcerned with other people's opinion and how other people see them. Therefore, consumer independence is negatively related to materialism; because materialistic people are self-conscious and have a strong concern that how they appear to others (Kasser, 2002). Following this, the shape of consumption, loyalty, independence and materialism, and the values which form the basis of these attitudes would make marketer's insights necessary for planning marketing strategies. Therefore, the purpose of this research was to test the relationships among materialism, perceived social status, status consumption, impulse buying, conspicuous consumption, brand loyalty, and consumer independence.

\section{Materialism}

Materialism is defined as an orientation which views material goods and money important for personal happiness and social progress (Ward \& Wackman, 1971). Belk (1984), Belk and Pollay (1985), Ger and Belk (1996) developed definitions and suggested that materialism was a function of one's personality reflecting traits of possessiveness, envy, and non-generosity. Following this, Richins and Dawson (1992) discussed materialism differently than Belk. They describe this concept as a concept where individuals have material acquisition at the nub of their lives and view these material possessions as the source of their happiness. They believe that materialistic consumers judge personal success as a function of the quality of possessions owned (Richins \& Dawson, 1992). In the same line of the argument, Richins and Dawson scale in 1992 contains three measures, namely success, centrality, and happiness. As a result of these studies, Richins \& Dawson and Belk's scale dimensions have been used together 'success, centrality, happiness, and envy' (Podoshen, Li, \& Zhang, 2011). 
Consumers who value materialism put obtained of products at the focus of their lives (Rokeach, 1973) and success is basic to set plans and aim of life (Daun, 1983). As for materialists, this success is a basic source of satisfaction or dissatisfaction and happiness or unhappiness, instead of personal relationships, experiences or contributions. Also, a materialist feels envy or displeasure when another person is upper to them in terms of happiness, success, prestige or possessions (Podoshen et al., 2011). Centrality refers to consumers' tendency to put importance on possessions at the center of their lives. Likewise, they purchase some products even though they are not important or necessary (Richins \& Dawson, 1992).

According to the the literature, materialism has been linked to various consumer behaviour. The examples of this behavior include social consumption motivation (Fitzmaurice \& Comegys, 2006), compulsive buying (Rindfleisch, Burroughs, \& Denton, 1997; Roberts, Manolis, \& Tanner, 2003), impulse buying (Bae, 2012; Beatty \&Elizabeth Ferrell, 1998; Podoshen \& Andrzejewski, 2012), brand perception (Kamineni, 2005), brand loyalty (Ailawadi, Neslin, \& Gedenk, 2001), attitude towards advertising (Yoon, 1995), social influence conformity (Schroeder \& Dugal, 1995), perceived social status (Fah et al., 2011; Fischer \& Gainer, 1991), status consumption and consumer independence (Goldsmith \& Clark, 2012), conspicuous consumption (Podoshen et al., 2011), and self-esteem (Deci \& Ryan, 1995).

\section{Perceived Social Status and Status Consumption}

Consumers had a different perception and need towards the product because they have different personality and background. Studies clearly show that materialistic consumers have disposed to spend money on mostly unnecessary or unimportant things (Liao \& Wang, 2009). The aim of these consumptions was the advancement of their perceived social status (Christopher, Marek, \& Carroll, 2004) and also the enhancement of their self-esteem (Tatzel, 2002). They purchase luxurious brand to signal their wealth and success, or at least make others perceive them successful (Liao \& Wang, 2009). So, they select good as a means of social approval as it delivers meaning in social interaction processes.

Status consumption defined similar type with perceived social status in literature because perceived social status is the beginning of status consumption. According to some of these definitions, some materialists are motivated to obtain goods to show both themselves and the environment to the others for the attainment of status in society (Eastman, Goldsmith, \& Flynn, 1999).

Consumers of greater materialistic tendencies are specially adapted to the social meanings of goods and it seems reasonable that materialists may enjoy sharing their social information with others through their acting. This material view is a symbolic representation of consumers' own images that they want to express to others. These explanations show that status consumption is an outcome of perceived social status and materialism, therefore, represents a significant relationship among perceived social status, status consumption, and materialism (Goldsmith \& Clark, 2012; Jalees, 2007).

\section{Conspicuous Consumption}


Some consumers buy certain goods hoping to be seen more favorably in the greater social hierarchy. In other words, use of conspicuous consumption provide more social status (Mullins, 1999). Especially if the conspicuous products have a high acceptance by the public (Richins, 1994). Materialistic consumers choose expensive products of known brands (Prendergast \& Wong, 2003); because they want to be perceived as having a high level of brand awareness by other people and in this way, they strength themselves. Sometimes they may perform by purchasing counterfeit luxury goods. Materialistic consumers show tendency towards feeling less satisfaction and happiness in their life and they have a tendency toward conspicuous consumption, because they do not have any meaningful relationships with others (Richins \& Dawson, 1992; Ryan \& Dziurawiec, 2001). Also, material products and conspicuous consumption have different meaning such as gaining social status, being involved in a group, showing high status to other people, having low self-confidence (Watson, 2003).

\section{Impulse Buying}

An 'impulse buying definition' is similar to 'unplanned purchasing'; but it is more than unplanned purchasing and it needs to impulse for buying. This impulse is felt suddenly and strongly and is often overwhelming. Rookh (1987) defined impulse buying concept as "a consumer experiences an unexpected, often strong and determined urge to buy something immediately." Then, this definition slightly extended by Beatty and Elizabeth Ferrell (1998). They consider impulse buying as an unanticipated and instant buying with no pre-shopping purpose either to buy the particular product category or to fulfill a certain buying task. The behavior appears after encountering an urge to buy and it seems to occur as a result of a sudden impulse and without a lot of reflection (Podoshen \& Andrzejewski, 2012).

Studies support a clear link between materialism and impulse buying. Tatzel's (2002) work show that spending request and density of materialism and consumers have a positive attitude toward debt and impulsive buying. Also, before than Tatzel's research, Belk (1995) stated that the materialist's consumer may be obsessed or addicted to spending and this tendency means to buy now and think later. There are different researches that are consistent with these results including Bourdieu (1984), McCracken (1988), Dittmar, Beattie, and Friese (1995), and Featherstone (2007). In addition, material products are consumed not only for functional meaning but also as symbolic meaning. These products are mostly purchased impulsively to reflect self-identity.

\section{Brand Loyalty}

Brand loyalty defined similarly with repeat purchasing behavior in some study but it has certain property distinguished from repeat purchasing behavior. These properties include nonrandom, behavioral response expressed over time which is a function of decision making or evaluative processes; and it is the most important difference for brand loyalty, which is based on brand commitment (Bloemer \& Kasper, 1995). In addition, some classes and status conscious consumers may tend to buy specific brands for reducing risk probability (Palumbo \& Herbig, 2000). Similarly, materialistic societies rely on world possessiveness for happiness and they will avoid the unhappiness derive from purchasing different brands and presumably they will continue buying products that they believe make them happy (Ailawadi et al., 2001). 
Faced with this situation, consumers may choose self-worth and happiness which is more important than other factors. These factors are associated with changing behaviors. Hence, they will continue to purchase products of the same brand (Troisi, Christopher, \& Marek, 2006).

\section{Consumer Independence}

Consumers often seek information from others before purchasing in order to reduce the risk of making bad decisions. In other words, they trust on information provided by other people. This social influence is named 'informational influence' (Bearden, Netemeyer, \& Teel, 1989; Bearden \& Rose, 1990; Goldsmith \& Clark, 2012). When consumers want to be seen as a member of a specific group, gain acceptance by this or different group, they tend to be affected by these people's purchasing decision: In this way they can express themselves. Related to these terms are "conformity" and "susceptibility to interpersonal influence" (Bearden et al., 1989). Faced with this situation, consumers may choose in three different ways; they can follow the others, revolt against others or they may ignore the influence of others and may not respond. This last response is called consumer independence (Clark, 2006).

Independent consumers are often not interested in the opinions of others and how others see them. This individual runs counter to that of the highly materialistic person because materialism is linked to low self-esteem and insecurity. Materialistic people seem to be influenced by external rewards and praise; they are self-conscious and have a powerful concern with how they appear to others (Kasser, 2002). For this reason, as the level of materialism increases, there is a good cause to recommend that consumers be less independent. In addition, other research observed that consumer independence, unlike materialism, is positively related to some concepts such as self-sufficiency, need for uniqueness, and self-confidence, and negatively related to social motivations for consumption, susceptibility to normative social influence, and prestige sensitivity (Clark, 2006). Therefore, a negative relation between materialism and consumer independence seems extremely obvious.

\section{Research Hypotheses}

The following research hypotheses guided the study:

$\mathbf{H}_{1}$ : Materialism is positively associated with status consumption.

$\mathbf{H}_{2}$ : Materialism is positively associated with perceived social status.

$\mathbf{H}_{3}$ : Materialism is positively associated with conspicuous consumption.

$\mathbf{H}_{4}$ : Materialism is positively associated with impulse buying.

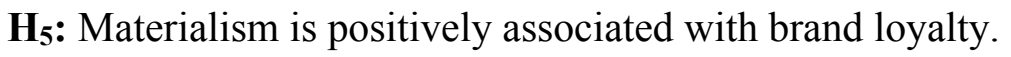

$\mathbf{H}_{6}$ : Materialism is negatively associated with consumer independence.

\section{Method}

Data were collected using a face to face interview with the help of marketing researchers specializing in consumer surveys. A total of 412 responders participated in the study. The sample of the study consisted of individuals who were over the age of 18 living in the city center of Erzurum. The questionnaire consisted of 47 five-point Likert scale items aimed at measuring materialism, social status, status consumption, impulse buying, conspicuous consumption, brand loyalty, and consumer independence. The other part of the questionnaire consisted of 6 items aimed at measuring demographic factors. 
We took advantage of existing scales to measure all constructs. For materialism, we used Richins and Dawson's (1992) and Belk's (1984) modified version of materialism scale. We used this particular scale because it conceptualizes materialism as cognitive beliefs and because it has been used in the recent literature with a high degree of reliability (Ahuvia \& Wong, 2002; Podoshen et al., 2011). Perceived social status as adopted by Fischer and Gainer (1991), status consumption and consumer independence was adopted by Clark (2006), impulse buying was adopted by Beatty and Elizabeth Ferrell (1998), and conspicuous consumption by Chung and Fischer (2001), which is a mixture of previously utilized measures developed by Moschis (1981), Lumpkin and Darden (1982) and lastly, brand loyalty was adopted by Ailawadiet al. (2001).

Figure 1 presents the research model.

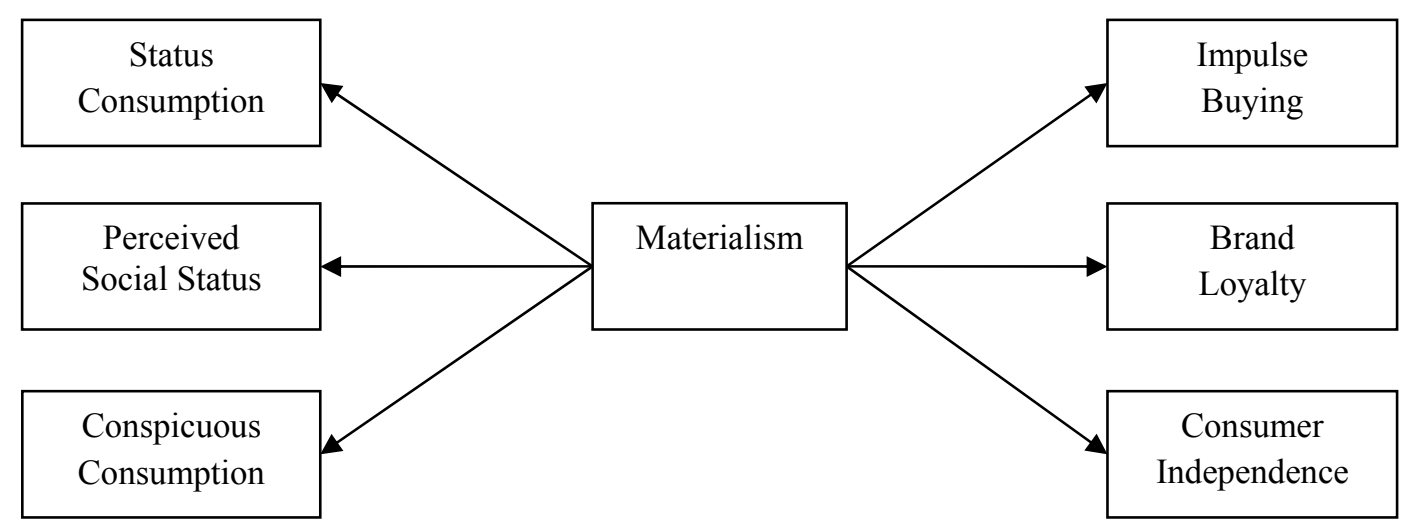

Figure 1. Research model

\section{Results}

Participants' ages ranged from 24 to 29 with $38.6 \%$. More than half of the total participants were female (50.2\%) and their income was 3501-4000 Turkish lira (\%42.5). Additionally, $37.9 \%$ of the participants had an undergraduate degree and $37.4 \%$ were public sector employees.

Considering the highest mean of research variable, the following expression had the highest average; in status consumption "a product is more valuable to me if it has some snob appeal." (4.39), in perceived social status "buying expensive and apparel things is symbolic of higher living standard" (4.37), in conspicuous consumption "before purchasing a product, it is important to know what others think of people who use certain brands or products I am considering" (4.42), in impulse buying "when I go shopping, I buy things that I had not intended to purchase." (4.28), in brand loyalty "I am willing to make an effort to search for my favorite brand." (2.76), in consumer independence "when I'm buying something, my personal preferences and tastes are more important to me than the opinions of others." (3.87), in materialism "happiness" (4.23) expression was found to have the highest average. According to these values consumers, prefer snob appeal, view expensive things are symbolic of higher living standard, they take care of what other people think about the brands they buy, they are buying impulse, they are loyal to the brand and independence. 
Before testing the structural model, a Confirmatory Factor Analysis (CFA) was conducted. The results of confirmatory factor analysis are shown in Table 1.

Table 1

Standardized Path Coefficients of the CFA

\begin{tabular}{cccccc}
\hline Items & $\begin{array}{c}(\mathrm{t}) \\
\text { Value }\end{array}$ & $\begin{array}{c}\text { Standardized } \\
\text { Loading }\end{array}$ & Error Variances & $\mathrm{R}^{2}$ & Cronbach's Alpha \\
\hline SC1 & 10.54 & 0.59 & 0.08 & 0.35 & \\
SC2 & 10.49 & 0.58 & 0.08 & 0.34 & 0.71 \\
SC3 & 10.54 & 0.67 & 0.11 & 0.45 & \\
SC4 & 9.14 & 0.50 & 0.08 & 0.25 & 0.64 \\
PSS1 & 8.95 & 0.53 & 0.12 & 0.28 & \\
PSS2 & 8.62 & 0.63 & 0.13 & 0.40 & 0.24 \\
PSS3 & 8.95 & 0.49 & 0.09 & 0.38 & \\
CC1 & 8.46 & 0.62 & 0.16 & 0.32 & 0.72 \\
CC2 & 8.14 & 0.57 & 0.13 & 0.26 & \\
CC3 & 8.46 & 0.51 & 0.08 & 0.40 & \\
CC4 & 8.55 & 0.63 & 0.15 & 0.28 & \\
IB1 & 9.69 & 0.53 & 0.07 & 0.53 & \\
IB2 & 9.22 & 0.73 & 0.09 & 0.66 & \\
IB3 & 13.35 & 0.81 & 0.08 & 0.36 & \\
BL1 & 12.81 & 0.81 & 0.09 & 0.46 & \\
BL2 & 10.52 & 0.56 & 0.06 & 0.45 & \\
BL3 & 12.81 & 0.68 & 0.06 & 0.27 & \\
CI1 & 8.59 & 0.67 & 0.12 & 0.37 & \\
CI2 & 7.9 & 0.52 & 0.10 & 0.25 & \\
CI3 & 8.5 & 0.61 & 0.10 & 0.20 & \\
CI4 & 7.66 & 0.50 & 0.10 & 0.61 & \\
CI5 & 7.05 & 0.45 & 0.09 & 0.41 & \\
Success & 13.98 & 0.78 & 0.09 & 0.44 & \\
Centrality & 13.33 & 0.64 & 0.52 & 0.44 & \\
Happiness & 13,98 & 0.66 & 0.05 & \\
Envy & 13.91 & 0.66 & 0.06 & & \\
\hline
\end{tabular}

Table 2 exhibits the fit index for CFA.

Table 2

Fit Index for CFA

\begin{tabular}{lll}
\hline Index & Structural Model's values & Acceptable Compliance \\
\hline Chi-Square $\left(\mathrm{X}^{2}\right)$ & 732.20 & \\
df & 270 & \\
$\left(\mathrm{X}^{2}\right) /$ df & 2.7 & $1-5$ \\
$\mathrm{p}$-value & 0.00 & \\
RMSEA & 0.06 & $0.05 \leq \mathrm{RMSEA} \leq 0.10$ \\
RMR & 0.07 & $0.05 \leq \mathrm{RMR} \leq 0.08$ \\
NFI & 0.91 & $0.90 \leq \mathrm{NFI} \leq 0.1$ \\
CFI & 0.97 & $0.95 \leq \mathrm{CFI} \leq 0.1$ \\
GFI & 0.94 & $0.90 \leq \mathrm{GFI} \leq 0.1$ \\
\hline
\end{tabular}


In Table 2 (X2)/df ratio was found to be 2.7 below the reference value. RMSEA is 0.06 and it was in the acceptable level. RMR, NFI, CFI, GFI levels also are seen to be within acceptable limits. Figure 2 illustrates the Structural model.

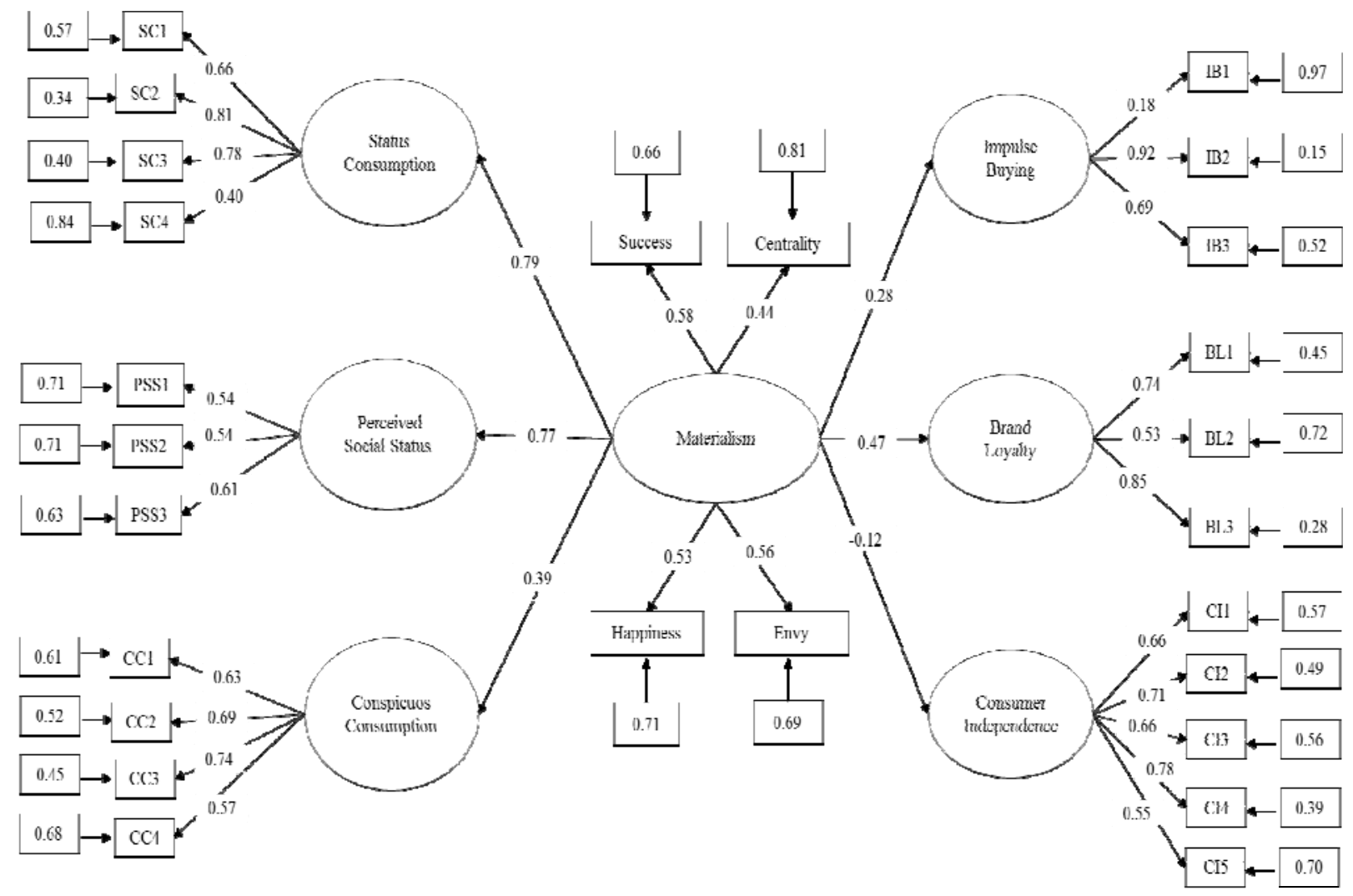

Figure 2. Structural model

Table 3 represents the standardized path coefficients of the structural model.

Table 3

Standardized Path Coefficients of the Structural Model

\begin{tabular}{|c|c|c|c|c|}
\hline Paths Statistically Significant & $\begin{array}{c}(\mathrm{t}) \\
\text { Value }\end{array}$ & $\begin{array}{l}\text { Standardized } \\
\text { Loading }\end{array}$ & $\begin{array}{c}\text { Error } \\
\text { Variances }\end{array}$ & $\mathrm{R}^{2}$ \\
\hline Materialism $\longrightarrow$ Status Consumption & 8.70 & 0.79 & 0.37 & 0.63 \\
\hline Materialism $\longrightarrow$ Perceived Social Status & 6.38 & 0.77 & 0.41 & 0.59 \\
\hline Materialism $\longrightarrow$ Conspicuous Consumption & 4.60 & 0.39 & 0.84 & 0.16 \\
\hline Materialism $\longrightarrow$ Impulse Buying & 2.07 & 0.28 & 0.92 & 0.08 \\
\hline Materialism $\longrightarrow$ Brand Loyalty & 5.65 & 0.47 & 0.78 & 0.22 \\
\hline Materialism $\longrightarrow$ Consumer Independence & -1.52 & -0.12 & 0.99 & 0.014 \\
\hline
\end{tabular}

Analyzing the standard values for model parameters, the coefficients of the variables $t$ is seen to be significant, excluding Consumer Independence. In this context, $\mathrm{H}_{1}, \mathrm{H}_{2}, \mathrm{H}_{3}, \mathrm{H}_{4}$, and $\mathrm{H}_{5}$ were accepted. Regarding the standardized regression coefficients, materialism affects status consumption. However, the $t$ value of consumer independent does not have a significant explanatory; following this, $\mathrm{H}_{6}$ which indicated that materialism is negatively associated with consumer independence was rejected.

Standard values for the parameters of the observed variables is examined; it is seen that $t$ values are meaningful. At the same time, $\mathrm{R} 2$ which is the explanatory coefficient shows that description of the latent variables by the observed variables. 
Table 4 shows the fit index for structural model.

Table 4

Fit Index for Structural Model

\begin{tabular}{lcc}
\hline Index & Structural Model's values & Acceptable Compliance \\
\hline Chi-Square $\left(\mathrm{X}^{2}\right)$ & 588.96 & \\
$\mathrm{df}$ & 318 & \\
$\left(\mathrm{X}^{2}\right) / \mathrm{df}$ & 1.8 & $1-5$ \\
$\mathrm{p}$-value & 0.00 & \\
RMSEA & 0.05 & $0.05 \leq \mathrm{RMSEA} \leq 0.10$ \\
RMR & 0.07 & $0.05 \leq \mathrm{RMR} \leq 0.08$ \\
NFI & 0.90 & $0.90 \leq \mathrm{NFI} \leq 0.1$ \\
CFI & 0.91 & $0.95 \leq \mathrm{CFI} \leq 0.1$ \\
GFI & 0.95 & $0.90 \leq \mathrm{GFI} \leq 0.1$ \\
\hline
\end{tabular}

In Table $4,\left(\mathrm{X}^{2}\right) / \mathrm{df}$ ratio was found to be 1.8 below the reference value. RMSEA is 0.05 and it is in the acceptable level. RMR, NFI, CFI, and GFI levels are also seen to be within acceptable limits.

\section{Discussion and Conclusion}

The purpose of the present study was to investigate the relationships among materialism, social status, status consumption, impulse buying, conspicuous consumption, brand loyalty and consumer independence. Our data supported five hypotheses. Materialism was positively associated with social status, status consumption, impulse buying, conspicuous consumption, and brand loyalty. The findings were consistent with previous studies but there was not found a significant relation between materialism and independence. Therefore, a hypothesis was not supported.

The study found that there exists a link between materialism and perceived social status and status consumption. Materialist consumer has high perceived social status and status consumption. As the level of materialism increases, there is also an increased desire to purchase products in order to obtain status. These people are in the pursuit of finding happiness by having material possessions. Thus, possessing material goods, especially status goods are very important for these people because they use these products to communicate with other people and there are good reasons to seek status. Materialism also seems to be related to the acquisition of good for the status and increasing the social prestige of their owners in the eyes of others. That is, when the tendency of materialism is low, individuals are less interested in buying status goods. Also, our work supports beliefs that exist the relation between materialism and impulse buying. In terms of impulse buying and its relationship to materialism is a psychological process. Materialists have high impulse buying tendencies; because if materialism increases, impulse buying will increase. Our data show that materialism gives rise to the need for acquiring goods that is the symbol of prestige. Therefore, the process of buying goods is not only central to the individual but is also related to the reaction received by others because the goods are purchased for social status within society. In this case it is understood that there is a relationship between materialism and conspicuous consumption. We found that materialism relates positively to brand loyalty. This means that consumers who have high materialistic dispositions show more brand loyalty. Individuals, in this way, escape from 
uncertainty and seek to reduce the risk of unhappiness. That is, consumers do not buy for practical use of certain brands, they buy for the sake of obtaining status and power.

Given the data in this study, the findings are consistent with the profile of materialistic behavior and its consequences. Connections between these consumer dispositions and materialism tools may give opportunities to focus on the sustainable strategies of marketing managers. If the marketer desires to be successful, their products should support a lifestyle centered on materialism. Also, marketers should think of promoting and meeting consumer needs and establish long-term relationships with consumers. Consequently, marketers should better examine the societal implications of their actions. So, marketers with strong brands are able to take advantage of consumers with high materialistic dispositions. When it comes to companies, if they have a strong brand, this can be viewed positively. In this regard, firms that implement strategy and marketing communications may advantage over competing firms when social responsibility and consumers' long-term well-being are in tune. In this way, firms may also benefit by finding an increase in customer trust and satisfaction. Moreover, remember that there are negative effects of materialism. Marketers and consumers consider the implications of debt, short-term gains in revenue. This situation may result from unhappiness and destructive behaviors on a societal level. To summarize, we believe that managers, firms, and related units will find our conclusions beneficial. Besides, this information may be beneficial for macro or consumer dispositions oriented other units.

The findings of this study should be viewed within the context of its limitations. Firstly, we gathered data from respondents residing in the Erzurum in Turkey. Therefore, the results should not generalize across the entire young adult populations in Turkey. It is possible that attitudes regarding materialism and its related concepts may differ based on geographic region. Future research may examine these differences between different groups of Turkey or of Erzurum consumers. Moreover, future researchers may investigate the impact of possessions on the family. They may use empirical tests to determine which types of variables are more effective. Also, they can be done by defining a certain product group.

\section{References}

Ahuvia, A. C., \& Wong, N. Y. (2002). Personality and values based materialism: Their relationship and origins. Journal of Consumer Psychology, 12(4), 389-402.

Ailawadi, K. L., Neslin, S. A., \& Gedenk, K. (2001). Pursuing the value-conscious consumer: Store brands versus national brand promotions. Journal of Marketing, 65(1), 71-89.

Bae, S. Y. (2012). Understanding ethical consumers: Assessing the moderating effects of price sensitivity, materialism, impulse buying tendency, and clothing involvement. Colorado State University.

Bearden, W. O., Netemeyer, R. G., \& Teel, J. E. (1989). Measurement of consumer susceptibility to interpersonal influence. Journal of Consumer Research, 15, 473-481.

Bearden, W. O., \& Rose, R. L. (1990). Attention to social comparison information: An individual difference factor affecting consumer conformity. Journal of Consumer Research, 16(4), 461-471.

Beatty, S. E., \& Elizabeth Ferrell, M. (1998). Impulse buying: Modeling its precursors. Journal of Retailing, 74(2), $161-167$.

Belk, R. W. (1984). Three scales to measure constructs related to materialism: Reliability, validity, and relationships to measures of happiness. Advances in Consumer Research, 11, 291-297.

Belk, R. W. (1987). Material values in the comics: A content analysis of comic books featuring themes of wealth. Journal of Consumer Research, 14(1), 26-42.

Belk, R. W. (1995). Collecting as luxury consumption: Effects on individuals and households. Journal of Economic Psychology, 16(3), 477-490. 
Belk, R. W., \& Pollay, R. W. (1985). Materialism and magazine advertising during the twentieth century. Advances in Consumer Research, 12(1), 394-398.

Bloemer, J. M., \& Kasper, H. D. P. (1995). The complex relationship between consumer satisfaction and brand loyalty. Journal of Economic Psychology, 16(2), 311-329.

Bourdieu, P. (1984). Distinction: A social critique of the judgement of taste (R. Nice, Trans.). Cambridge, MA: Harvard University Press.

Christopher, A. N., Marek, P., \& Carroll, S. M. (2004). Materialism and attitudes toward money: An exploratory investigation. Individual Differences Research, 2(2), 109-117.

Chung, E., \& Fischer, E. (2001). When conspicuous consumption becomes inconspicuous: The case of the migrant Hong Kong consumers. Journal of Consumer Marketing, 18(6), 474-487.

Clark, R. A. (2006). Consumer independence: Conceptualization, measurement and validation of a previously unmeasured social response tendency. Florida State University, Tallahassee, FL.

Daun, A. (1983). The materialistic life-style: Some socio-psychological aspects. In L. Uusitalo (Ed.), Consumer behavior and environmental quality, (pp. 6-16). New York: St. Martin's.

Deci, E. L., \& Ryan, R. M. (1995). Human autonomy: The basis for the self-esteem. In M. Kernis (Ed.), Efficacy, agency, and self-esteem (pp. 31-49). New York: Plenum Publishing Co.

Dittmar, H., Beattie, J., \& Friese, S. (1995). Gender identity and material symbols: Objects and decision considerations in impulse purchases. Journal of Economic Psychology, 16(3), 491-511.

Eastman, J. K., Goldsmith, R. E., \& Flynn, L. R. (1999). Status consumption in consumer behavior: Scale development and validation. Journal of Marketing Theory \& Practice, 7(3), 41-52.

Fah, B. C. Y., Foon, Y. S., \& Osman, S. (2011). An exploratory study of the relationships between advertising appeals, spending tendency, perceived social status and materialism on perfume purchasing behavior. International Journal of Business \& Social Science, 2(10), 202-208.

Featherstone, M. (2007). Consumer culture and postmodernism. London: Sage.

Fischer, E., \& Gainer, B. (1991). I shop therefore I am: The role of shopping in the social construction of women's identities. In G. A. Costa (Ed.), Gender and consumer behavior (pp. 350-357). Salt Laje City: University of Utah Press.

Fitzmaurice, J., \& Comegys, C. (2006). Materialism and social consumption. The Journal of Marketing Theory \& Practice, 14(4), 287-299.

Ger, G., \& Belk, R. W. (1996). Cross-cultural differences in materialism. Journal of Economic Psychology, 17(1), 55-77.

Goldsmith, R. E., \& Clark, R. A. (2012). Materialism, status consumption, and consumer independence. The Journal of Social Psychology, 152(1), 43-60.

Jalees, T. (2007). Identifying determinants of compulsive buying behavior. Market Forces, 3(2), 30-51.

Kamineni, R. (2005). Influence of materialism, gender and nationality on consumer brand perceptions. Journal of Targeting, Measurement \& Analysis for Marketing, 14(1), 25-32.

Kasser, T. (2002). The high price of materialism. Cambridge, Mass: MIT Press.

Liao, J., \& Wang, L. (2009). Face as a mediator of the relationship between material value and brand consciousness. Psychology \& Marketing, 26(11), 987-1001.

Lumpkin, J. R., \& Darden, W. R. (1982). Relating television preference viewing to shopping orientations, life styles, and demographics: The examination of perceptual and preference dimensions of television programming. Journal of Advertising, 11(4), 56-67.

McCracken, G. (1988). The long interview. New York: Sage Publications.

Moschis, G. P. (1981). Patterns of consumer learning. Journal of the Academy of Marketing Science, 9(2), 110-126.

Mullins, P. R. (1999). Race and the genteel consumer: Class and African-American consumption. Historical Archaeology, $33(1), 22-38$.

Palumbo, F., \& Herbig, P. (2000). The multicultural context of brand loyalty. European Journal of Innovation Management, $3(3), 116-125$.

Podoshen, J. S., \& Andrzejewski, S. A. (2012). An examination of the relationships between materialism, conspicuous consumption, impulse buying, and brand loyalty. The Journal of Marketing Theory \& Practice, 20(3), 319-334.

Podoshen, J. S., Li, L., \& Zhang, J. (2011). Materialism and conspicuous consumption in China: A cross-cultural examination. International Journal of Consumer Studies, 35(1), 17-25. 
Prendergast, G., \& Wong, C. (2003). Parental influence on the purchase of luxury brands of infant apparel: An exploratory study in Hong Kong. Journal of Consumer Marketing, 20(2), 157-169.

Richins, M. L. (1994). Special possessions and the expression of material values. Journal of Consumer Research, 21(3), 522533.

Richins, M. L., \& Dawson, S. (1992). A consumer values orientation for materialism and its measurement: Scale development and validation. Journal of Consumer Research, 19, 303-316.

Rindfleisch, A., Burroughs, J. E., \& Denton, F. (1997). Family structure, materialism, and compulsive consumption. Journal of Consumer Research, 23(4), 312-325.

Roberts, J. A., Manolis, C., \& Tanner, J. F. (2003). Family structure, materialism, and compulsive buying: A re-inquiry and extension. Journal of the Academy of Marketing Science, 31(3), 300-311.

Rokeach, M. (1973). The nature of human values. New York: Free press.

Rookh, D. W. (1987). The buying impulse. The Journal of Consumer Research, 14(2), 189-199.

Ryan, L., \& Dziurawiec, S. (2001). Materialism and its relationship to life satisfaction. Social Indicators Research, 55(2), 185197.

Schroeder, J. E., \& Dugal, S. S. (1995). Psychological correlates of the materialism construct. Journal of Social Behavior \& Personality, 10, 243-253.

Tatzel, M. (2002). "Money worlds" and well-being: An integration of money dispositions, materialism and price-related behavior. Journal of Economic Psychology, 23(1), 103-126.

Troisi, J. D., Christopher, A. N., \& Marek, P. (2006). Materialism and money spending disposition as predictors of economic and personality variables. North American Journal of Psychology, 8(3), 421-436.

Ward, S., \& Wackman, D. (1971). Family and media influences on adolescent consumer learning. American Behavioral Scientist, 14(3), 415-427.

Watson, J. J. (2003). The relationship of materialism to spending tendencies, saving, and debt. Journal of Economic Psychology, 24(6), 723-739.

Yoon, K. (1995). Comparison of beliefs about advertising, attitude toward advertising, and materialism held by African Americans and Caucasians. Psychological Reports, 77(2), 455-466. 